\title{
RNAi-based Cancer Therapeutics: Are we there yet?
}

\section{Vaibhav Saxena*}

Boston Biomedical, Inc., USA

"Corresponding author: Vaibhav Saxena, Postdoctoral Scientist, Boston Biomedical, Inc., USA, Tel: 917.455.6857; E-mail: vaibhavsx@gmail.com

Received date: October 30, 2014, Accepted date: November 19, 2014, Published date: November 26, 2014

Copyright: (c) 2014 Saxena V. This is an open-access article distributed under the terms of the Creative Commons Attribution License, which permits unrestricted use, distribution, and reproduction in any medium, provided the original author and source are credited.

\begin{abstract}
RNAi-based therapeutics remains one of the most promising strategies for the effective cancer treatment due to its high target-specificity, precise mechanism of action, greater potency and reduced side effects. Although, tremendous progress and advances have been made in the past few years to develop nanotechnology-based efficient non-viral delivery systems, there are still many hurdles and challenges that must be conquered to achieve the target of clinically relevant formulation in terms of safety, specificity and efficacy.
\end{abstract}

\section{Introduction}

Cancer is the leading cause of death worldwide and according to WHO accounted for almost 8.2 million deaths in 2012 [1]. Clinically, chemotherapy plays a vital role in combating cancer, followed by surgery and radiotherapy. Chemotherapy involves the utilization of chemotherapeutic or cytotoxic agents, which are primarily employed to inhibit or control the rate of growth of tumor tissues. Despite, the availability of potent anti-cancer drugs in the clinic, by large, the use of these cytotoxic agents impose some limitations, such as the nonspecific distribution at the tumor site, which results in the insufficient penetration of such drugs into the tumor tissues [2]. Next, the nonselective action of these agents results in the damage to the normal healthy cells, causing extreme side effects to the body and further limits the dose or its frequency of dosing [3]. Another important limitation associated with the use of cytotoxic agents is the development of multi-drug resistance (MDR) [4]. All these cases, overall reduces the efficacy of chemotherapeutic compounds.

\section{RNAi in Cancer Therapeutics}

RNA interference (RNAi), mediated by short double-stranded RNA (dsRNA) molecules is a sequence-specific post-transcriptional gene silencing phenomenon, resulting in the degradation of target mRNA and subsequently its expression [5]. In the last decade or so, the RNA interference (RNAi) technology, mediated primarily by small interfering RNA (siRNAs) and micro RNA (miRNAs) has emerged as one of the most promising strategies for cancer therapeutics [6-8], primarily due to its high specificity, precise mechanism of action and potency [9]. The strategy is also advantageous in terms of its capability to target multiple oncogenes simultaneously. In addition to this, the RNAi technology aids to improve the efficacy of chemotherapeutic agents by overcoming the multi-drug resistant (MDR) effects.

\section{Challenges}

Despite, some major advances in this field of therapeutics, there are, however some challenges that needs to be overcome, such as the biological safety, serum stability, off-target effects and effective in vivo delivery [10]. A significant progress has been made in terms of minimizing the off-target effects, thus improving the precision and safety of such drugs [11]. Various chemical-modifications to the oligonucleotide backbone have also been investigated, resulting in the improved serum stability [12]. From the in vivo delivery standpoint, even though the viral-based vectors showed promise $[13,14]$, its safety has always been of concern and thus limits the use. In this scenario, the nanotechnology-based non-viral delivery vehicles became the preferred drug delivery choice [15], for its overall biological compatibility and enhanced in vivo delivery.

\section{Nanotechnology-based Delivery Strategies}

The nanotechnology-based strategies have made significant progress in the development of efficient non-viral delivery systems. Various promising nanoparticles (NPs) strategies that have been successful in depicting in vitro gene silencing and tumor reduction efficacy in animal models, safety in non-human primates and in few cases, have undergone clinical trial testing include, (A) Lipid based NPs: liposomes [16], lipoplexes [17,18], stable nucleic acid lipid nanoparticles (SNALP) [19,20] \& lipidoid [21], polycation liposomes [22,23], (B) Polymeric NPs: both natural and synthetic, includes cyclodextrin [24], chitosan [25], PLGA [26], polymeric micelles [27], PEI [28] \& dendrimers [29], (C) Inorganic NPs: calcium phosphate $\mathrm{CaP}$ [30], (D) Carbon-based materials, carbon nanotubes (SWNTs, MWNTs) [31,32], (E) Metal nanoparticles - Gold (Au) [33], Quantum dots (QDs) [34], silicon-based nanoparticles (MSNPs) [35] \& super paramagnetic iron oxide nanoparticles (SPIONs) [36] etc. In addition to this, atelocollagen-based delivery strategy also proved to be successful in few cases [37,38].

To develop a clinically-relevant effective nanoparticles delivery system, the nanoparticles (NPs) formulation also needs to overcome various extracellular and intracellular hurdles [39] such as, stability in blood serum, greater half-life for high enhanced permeability and retention (EPR) effect, ability to escape the reticuloendothelial system (RES), selective accumulation and penetration into the tumor tissues and final binding to the target tumor cells. The NPs must then be taken up the cells by the process of endocytosis, followed by the release of the intact siRNA in the cytoplasm by endo-lysosomal escape. The final step is the sequence-specific binding to the target mRNA and gene knockdown. 
Page 2 of 3

\section{Current State of Clinical Trials}

In recent times, RNAi based therapeutics has rapidly progressed from benchside to the patients in clinic. Currently, there are many clinical trials in progress, most of them in Phase-I/IIa, evaluating the safety and efficacy of such siRNA-based drugs for cancer therapeutics [40-44]. The detailed description of the various ongoing current clinical trial programs is mentioned in Table 1.

\begin{tabular}{|c|c|c|c|c|c|}
\hline Company & $\begin{array}{l}\text { Progra } \\
\text { m }\end{array}$ & $\begin{array}{l}\text { Target } \\
\text { Gene }\end{array}$ & $\begin{array}{l}\text { Delivery } \\
\text { System }\end{array}$ & Disease & $\begin{array}{l}\text { Stage of } \\
\text { Developme } \\
\text { nt }\end{array}$ \\
\hline $\begin{array}{l}\text { Alnylum } \\
\text { Pharmaceutic } \\
\text { als }\end{array}$ & $\begin{array}{l}\text { ALN- } \\
\text { VSP02 }\end{array}$ & $\begin{array}{l}\text { VEGF, } \\
\text { KSP }\end{array}$ & $\begin{array}{l}\text { Lipid } \\
\text { Nanoparticle } \\
\text { s (LNPs) }\end{array}$ & Liver Cancer & $\begin{array}{l}\text { Phase-I } \\
\text { Complete }\end{array}$ \\
\hline $\begin{array}{l}\text { Calando } \\
\text { Pharmaceutic } \\
\text { als }\end{array}$ & $\begin{array}{l}\text { CALAA- } \\
01\end{array}$ & RRM2 & $\begin{array}{l}\text { Cyclodextrin- } \\
\text { polymeric } \\
\text { Nanoparticle } \\
\text { s }\end{array}$ & Solid tumors & $\begin{array}{l}\text { Phase-I } \\
\text { Terminated }\end{array}$ \\
\hline $\begin{array}{l}\text { Enzon } \\
\text { Pharmaceutic } \\
\text { als }\end{array}$ & $\begin{array}{l}E Z N-29 \\
68\end{array}$ & HIF-1 $1 \alpha$ & $\begin{array}{l}\text { Naked LNA } \\
\text { antisense }\end{array}$ & $\begin{array}{l}\text { Solid } \\
\text { Tumors }\end{array}$ & $\begin{array}{l}\text { Phase-I } \\
\text { Complete }\end{array}$ \\
\hline Gradalis & $\begin{array}{l}\text { FANGT } \\
\text { M } \\
\text { Vaccine }\end{array}$ & furin & $\begin{array}{l}\text { Plasmid } \\
\text { encoding bi- } \\
\text { shRNA }\end{array}$ & $\begin{array}{l}\text { Advanced } \\
\text { Cancer, } \\
\text { Melanoma }\end{array}$ & $\begin{array}{l}\text { Phase-I } \\
\text { Complete/II }\end{array}$ \\
\hline $\begin{array}{l}\text { Silence } \\
\text { Therapeutics }\end{array}$ & Atu027 & PKN3 & $\begin{array}{l}\text { Liposome- } \\
\text { siRNA } \\
\text { complex }\end{array}$ & $\begin{array}{l}\text { Pancreatic, } \\
\text { Advanced } \\
\text { solid tumors }\end{array}$ & Phase-I/Ila \\
\hline Silenseed & $\begin{array}{l}\text { siG12D } \\
\text { LODER }\end{array}$ & KRAS & $\begin{array}{l}\text { Biodegradabl } \\
\text { e polymer } \\
\text { matrix }\end{array}$ & $\begin{array}{l}\text { Adenocarcin } \\
\text { oma of } \\
\text { pancreas }\end{array}$ & Phase-I/lla \\
\hline $\begin{array}{l}\text { Santaris } \\
\text { Pharma }\end{array}$ & $\begin{array}{l}\text { SPC299 } \\
6\end{array}$ & $\mathrm{Bcl}-2$ & $\begin{array}{l}\text { Locked } \\
\text { nucleic acid } \\
\text { (LNA) }\end{array}$ & $\begin{array}{l}\text { Chronic } \\
\text { Lymphocytic } \\
\text { Leukemia }\end{array}$ & Phase-I/II \\
\hline Tekmira & $\begin{array}{l}\text { TKM- } \\
\text { PLK1 }\end{array}$ & PLK1 & $\begin{array}{l}\text { Lipid } \\
\text { Nanoparticle } \\
\text { s (LNPs) }\end{array}$ & $\begin{array}{l}\text { GI-NET, } \\
\text { ACC, HCC }\end{array}$ & Phase-I/Ila \\
\hline
\end{tabular}

Table 1: Current RNAi based cancer therapeutics in clinical trials. (Note: ${ }^{\star}$ Data obtained from corporate websites, clinicaltrials.gov and published articles (as mentioned in the references). VEGF - vascular endothelial growth factor; KSP- kinesin spindle protein; RRM2 ribonucleotide reductase M2; HIF-1 (alpha) - hypoxia-induced factor; PKN3 - protein kinase N3; KRAS - V-Ki-ras2 Kirsten rat sarcoma viral oncogene homolog; Bcl-2: B-cell lymphoma 2; PLK1 - polo-like kinase I; ACC - adrenocortical carcinoma; GI-NET - gastrointestinal neuroendocrine tumors.)

\section{Conclusion \& Future Perspectives}

Recently, there is a lot of interest to develop RNAi based therapeutics, for its immense potential to revolutionize the future of medicine. For cancer therapy, the advancement in RNAi technology has paved the way for the development of more potent and effective therapies as it targets multiple oncogenes, aids in the reversal of MDR effect, enhances the clinical efficacy of existing chemotherapeutic compounds, and reduces the unwanted side effects. Though, the recent advances in the nanotechnology based non-viral delivery systems showed great potential and warrant its clinical development; however, to date, the success for such existing systems has been limited, primarily due to the toxicity issues and some additional challenges associated with the various stages of the delivery process. Hence, to further our understanding and progress in the field \& to develop the clinically relevant RNAi formulation, it would thus be beneficial to develop a novel, safe, biocompatible, efficacious and multifunctional nanoparticulate systems as personalized medicine for the near future.

\section{References}

1. Ferlay J, Steliarova-Foucher E, Lortet-Tieulent J, Rosso S, Coebergh JW, et al. (2013) Cancer incidence and mortality patterns in Europe: estimates for 40 countries in 2012. Eur J Cancer 49: 1374-1403.

2. Gutteridge WE (1985) Existing chemotherapy and its limitations. Br Med Bull 41: 162-168.

3. Creixell M, Peppas NA (2012) Co-delivery of siRNA and therapeutic agents using nanocarriers to overcome cancer resistance. Nano Today 7 : 367-379.

4. Liscovitch M, Lavie Y (2002) Cancer multidrug resistance: a review of recent drug discovery research. IDrugs 5: 349-355.

5. Bora RS, Gupta D, Mukkur TK, Saini KS (2012) RNA interference therapeutics for cancer: challenges and opportunities (review). Mol Med Rep 6: 9-15.

6. Lee JM, Yoon TJ, Cho YS (2013) Recent developments in nanoparticlebased siRNA delivery for cancer therapy. Biomed Res Int 2013: 782041.

7. Guo W, Chen W, Yu W, Huang W, Deng W (2013) Small interfering RNA-based molecular therapy of cancers. Chin J Cancer 32: 488-493.

8. Gandhi NS, Tekade RK, Chougule MB (2014) Nanocarrier mediated delivery of siRNA/miRNA in combination with chemotherapeutics agents for cancer therapy: Current progress and advances. J Control Release 194C: 238-256.

9. Rao DD, Wang Z, Senzer N, Nemunaitis J (2013) RNA interference and personalized cancer therapy. Discov Med 15: 101-110.

10. Guzman-Villanueva D, El-Sherbiny IM, Herrera-Ruiz D, Vlassov AV, Smyth HD (2012) Formulation approaches to short interfering RNA and MicroRNA: challenges and implications. J Pharm Sci 101: 4046-4066.

11. Fattal E, Bochot A (2008) State of the art and perspectives for the delivery of antisense oligonucleotides and siRNA by polymeric nanocarriers. Int J Pharm 364: 237-248.

12. Akhtar S, Benter IF (2007) Nonviral delivery of synthetic siRNAs in vivo. J Clin Invest 117: 3623-3632.

13. Couto LB, High KA (2010) Viral vector-mediated RNA interference. Curr Opin Pharmacol 10: 534-542.

14. Ma Y, Chan CY, He ML (2007) RNA interference and antiviral therapy. World J Gastroenterol 13: 5169-5179.

15. Takahashi Y, Nishikawa M, Takakura Y (2009) Nonviral vector-mediated RNA interference: its gene silencing characteristics and important factors to achieve RNAi-based gene therapy. Adv Drug Deliv Rev 61: 760-766.

16. Wu SY, McMillan NA (2009) Lipidic systems for in vivo siRNA delivery. AAPS J 11: 639-652.

17. Santel A, Aleku M, Keil O, Endruschat J, Esche V, et al. (2006) RNA interference in the mouse vascular endothelium by systemic administration of siRNA-lipoplexes for cancer therapy. Gene Ther 13: 1360-1370.

18. Strumberg D, Schultheis B, Traugott U, Vank C, Santel A, et al. (2012) Phase I clinical development of Atu027, a siRNA formulation targeting PKN3 in patients with advanced solid tumors. Int J Clin Pharmacol Ther 50: 76-78.

19. Zimmermann TS, Lee AC, Akinc A, Bramlage B, Bumcrot D, et al. (2006) RNAi-mediated gene silencing in non-human primates. Nature 441: 111-114. 
Page 3 of 3

20. Judge AD, Robbins M, Tavakoli I, Levi J, Hu L, et al. (2009) Confirming the RNAi-mediated mechanism of action of siRNA-based cancer therapeutics in mice. J Clin Invest 119: 661-673.

21. Shen H, Sun T, Ferrari M (2012) Nanovector delivery of siRNA for cancer therapy. Cancer Gene Ther 19: 367-373.

22. Kenjo E, Asai T, Yonenaga N, Ando H, Ishii T, et al. (2013) Systemic delivery of small interfering RNA by use of targeted polycation liposomes for cancer therapy. Biol Pharm Bull 36: 287-291.

23. Chen Y, Zhu X, Zhang X, Liu B, Huang L (2010) Nanoparticles modified with tumor-targeting scFv deliver siRNA and miRNA for cancer therapy. Mol Ther 18: 1650-1656.

24. Davis ME, Zuckerman JE, Choi CH, Seligson D, Tolcher A, et al. (2010) Evidence of RNAi in humans from systemically administered siRNA via targeted nanoparticles. Nature 464: 1067-1070.

25. Howard KA, Rahbek UL, Liu X, Damgaard CK, Glud SZ, et al. (2006) RNA interference in vitro and in vivo using a novel chitosan/siRNA nanoparticle system. Mol Ther 14: 476-484.

26. Wu ZW, Chien CT, Liu CY, Yan JY, Lin SY (2012) Recent progress in copolymer-mediated siRNA delivery. J Drug Target 20: 551-560.

27. Kim SH, Jeong JH, Lee SH, Kim SW, Park TG (2008) Local and systemic delivery of VEGF siRNA using polyelectrolyte complex micelles for effective treatment of cancer. J Control Release 129: 107-116.

28. Bonnet ME, Erbacher P, Bolcatto-Bellemin AL (2008) Systemic delivery of DNA or siRNA by linear polyethylenimine (L-PEI) does not induce an immune response. Pharm Research 25: 2972-2982.

29. Taratula O, Garbuzenko OB, Kirkpatrick P, Pandya I, Savla R, et al (2009) Surface-engineered targeted PPI dendrimer for efficient intracellular and intratumoral siRNA delivery. J Control Release 140: 284-293.

30. Li J, Yang Y, Huang L (2012) Calcium phosphate nanoparticles with an asymmetric lipid bilayer coating for siRNA delivery to the tumor. J Control Release 158: 108-114.

31. Al-Jamal KT, Toma FM, Yilmazer A, Ali-Boucetta H, Nunes A, et al (2010) Enhanced cellular internalization and gene silencing with a series of cationic Dendron-multiwalled carbon nanotubes: siRNA complexes. FASEB J 24: 4354-4365.

32. Podesta JE, Al-Jamal KT, Herrero MA, Tian BW, Ali-Boucetta H, et al. (2009) Antitumor activity and prolonged survival by carbon-nanotubemediated therapeutic siRNA silencing in a human lung xenograft model. Small 5: 1176-1185.

33. Kong WH, Bae KH, Jo SD, Kim JS, Park TG (2012) Cationic lipid-coated gold nanoparticles as efficient and non-cytotoxic intracellular siRNA delivery vehicles. Pharm Res 29: 362-374.
34. Tan WB, Jiang S, Zhang Y (2007) Quantum-dot based nanoparticles for targeted silencing of HER2/neu gene via RNA interference. Biomaterials 28: $1565-1571$

35. Meng H, Mai WX, Zhang H, Xue M, Xia T, et al. (2013) Codelivery of an optimal drug/siRNA combination using mesoporous silica nanoparticles to overcome drug resistance in breast cancer in vitro and in vivo. ACS Nano 7: 994-1005.

36. Lee JH, Lee K, Moon SH, Lee Y, Park TG, et al. (2009) All-in-one targetcell-specific magnetic nanoparticles for simultaneous molecular imaging and siRNA delivery. Angew Chem Int Ed Engl 48: 4174-4179.

37. Forootan SS, Bao ZZ, Forootan FS, Kamalian L, Zhang Y, et al. (2010) Atelocollagen-delivered siRNA targeting the FABP5 gene as an experimental therapy for prostate cancer in mouse xenografts. Int $J$ Oncol 36: 69-76

38. Minakuchi Y, Takeshita F, Kosaka N, Sasaki H, Yamamoto Y, et al. (2004) Atelocollagen-mediated synthetic small interfering RNA delivery for effective gene silencing in vitro and in vivo. Nucleic Acids Res 32: e109.

39. Cho K, Wang X, Nie S, Chen ZG, Shin DM (2008) Therapeutic nanoparticles for drug delivery in cancer. Clin Cancer Res 14: 1310-1316.

40. Tabernero J, Shapiro GI, LoRusso PM, Cervantes A, Schwartz GK, et al. (2013) First-in-humans trial of an RNA interference therapeutic targeting VEGF and KSP in cancer patients with liver involvement. Cancer Discov 3: 406-417.

41. Zuckerman JE, Gritli I, Tolcher A, Heidel JD, Lim D, et al. (2014) Correlating animal and human phase Ia/Ib clinical data with CALAA-0, a targeted, polymer-based nanoparticle containing siRNA. Proc Natl Acad Sci U S A 111: 11449-11454.

42. Jeong W, Rapisarda A, Park SR, Kinders RJ, Chen A, et al. (2014) Pilot trial of EZN-2968, an antisense oligonucleotide inhibitor of hypoxiainducible factor-1 alpha (HIF-1 $\mathrm{I} \pm$ ), in patients with refractory solid tumors. Cancer Chemother Pharmacol 73: 343-348.

43. Senzer N, Barve M, Kuhn J, Melnyk A, Beitsch P, et al. (2012) Phase I trial of "bi-shRNAi(furin)/GMCSF DNA/autologous tumor cell" vaccine (FANG) in advanced cancer. Mol Ther 20: 679-686.

44. Strumberg D, Schultheis B, Traugott U, Vank C, Santel A, et al. (2012) Phase I clinical development of Atu027, a siRNA formulation targeting PKN3 in patients with advanced solid tumors. Int J Clin Pharmacol Ther 50: 76-78. 